J. Biosci., Vol. 10, Number 2, June 1986, pp. 203-213. C Printed in India.

\title{
Decarboxylation of arginine and ornithine by arginine decarboxylase purified from cucumber (Cucumis sativus) seedlings
}

\author{
G. L. PRASAD and P. R. ADIGA \\ Department of Biochemistry, Indian Institute of Science, Bangalore 560012, India \\ MS received 26 December 1985; revised 15 April 1986
}

\begin{abstract}
A purified preparation of arginine decarboxylase from Cucumis sativus seedlings displayed ornithine decarboxylase activity as well. The two decarboxylase activities associated with the single protein responded differentially to agmatine, putrescine and $P i$. While agmatine was inhibitory ( $50 \%$ ) to arginine decarboxylase activity, ornithine decarboxylase activity was stimulated by about 3 -fold by the guanido arnine. Agmatine-stimulation of ornithine decarboxylase activity was only observed at higher concentrations of the amine. Inorganic phosphate enhanced arginine decarboxylase activity (2-fold) but ornithine decarboxylase activity was largely uninfluenced. Although both arginine and ornithine decarboxylase activities were inhibited by putrescine, ornithine decarboxylase activity was profoundly curtailed even at $1 \mathrm{mM}$ concentration of the diamine. The enzyme-activated irreversible inhibitor for mammalian ornithine decarboxylase, viz. $\alpha$-difluoromethyl ornithine, dramatically enhanced arginine decarboxylase activity (3-4 fold), whereas ornithine decarboxylase activity was partially $(50 \%)$ inhibited by this inhibitor. At substrate level concentrations, the decarboxylation of arginine was not influenced by ornithine and vice-versa. Preliminary evidence for the existence of a specific inhibitor of ornithine decarboxylase activity in the crude extracts of the plant is presented. The above results suggest that these two amino acids could be decarboxylated at two different catalytic sites on a single protein.
\end{abstract}

Keywords. Arginine decarboxylase; purification; ornithine decarboxylase; modulation; DFMO; dual activities.

\section{Introduction}

In the past, the involvement of ornithine decarboxylase (ODC) (EC 4.1.1.17) in putrescine biosynthesis in the plant systems was generally considered to be of minor consequence. However, in recent years, pronounced ODC activities have been demonstrated in a number of plant systems such as Helianthus tuberosus (Bagni and Speranza, 1977), tomato ovary cells in culture (Cohen et al., 1982), oat leaf protoplasts (Flores and Galston, 1982), peas (Dai et al., 1982), potatoes (Kaur-Sawhney et al., 1982), Phaseolus vulgaris (Palavan and Galston, 1982), mung bean seedlings (Altman et al., 1982) and barley (Kyariakidis, 1983) during experimental manipulation. Furthermore, two pathways for putrescine biosynthesis, involving both arginine decarboxylase (ADC) (EC 4.1.1.19) and ODC have been detected in Agrobacterium tumefaciens and in

\footnotetext{
Abbreviations used: ODC, Ornithine decarboxylase; ADC, arginine decarboxylase; DFMA, difluoromethyl arginine; DFMO, difluoromethyl ornithine; PLP, pyridoxal phosphate; PAGE, Polyacrylamide gel electrophoresis; SDS, sodium dodecyl sulphate; NEM, N-ethylmalieimide.
} 
normal and crown gall tissues of Scorzonera hispanica (Speranza and Bagni, 1977). Recently, Kyriakidis et al. (1983) have purified ODC from barley seedlings and found that a large portion of enzyme activity was localized in the nuclear fraction and the remainder in the cytoplasm. With the exception of this study, detailed investigations on the properties of plant ODC are meagre. The possibility that ODC rather than ADC, could be an important regulatory enzyme in plants under certain conditions was suggested by the finding that in tomato ovary cells during fruit setting and XD-cells of tobacco (Cohen et al., 1982; Heimer et al., 1979), ODC activity was enhanced nearly 30fold while ADC activity remained unchanged. Similarly, during profuse sprouting of potato tubers (Kaur-Sawhney et al., 1982), a 6-fold increase in ODC activity was encountered suggesting that ODC may be relatively of greater importance in this plant system also.

Recently, Prasad and Adiga (1985b) purified ADC from cucumber (Cucumis sativus) seedlings and studied some of its molecular properties. Although ODC activity could not be assayed in crude extracts of this plant system, it was intriguing to find that homogenous ADC preparation obtained from the plant seedlings, efficiently catalysed enzymic decarboxylation of ornithine also. In this paper, we provide evidence to support this observation and describe the responses of the dual enzyme activities associated with the purified protein to various ligands, besides comparing some of the properties of these two catalytic functions associated with the single protein.

\section{Materials and methods}

Difluoromethyl arginine (DFMA) and difluoromethyl ornithine (DFMO) were generous gifts of Merrell Dow Chemical Company, Cincinnatti, Ohio, USA. Sources of cucumber seeds, the method of their germination and seedling growth and of other chemicals were the same as Prasad and Adiga (1985b). $\left[1-{ }^{14} \mathrm{C}\right]-O r n i t h i n e ~(S p$ activity $59 \mathrm{mCi} / \mathrm{m} \mathrm{mol}$ ) was obtained from Radiochemical Centre, Amersham, England, while $\left[\mathrm{U}-{ }^{14} \mathrm{C}\right]$-L-arginine (Sp. activity $246 \mathrm{mCi} / \mathrm{m} \mathrm{mol}$ ) was obtained from Bhabha Atomic Research Centre, Bombay.

\section{Purification of $A D C$}

ADC from cucumber seedlings was purified according to a 3-step procedure developed in this laboratory (Prasad and Adiga, 1985b) involving ion exchange chromatography on DEAE-cellulose and gel filtration on Sephadex G-150. The protein fraction eluted in the void volume possessed ADC and ODC activities and was homogenous upon electrophoresis at $\mathrm{pH} 8.3$ or 4.3 on $7.5 \%$ polyacrylamide gels respectively (figure 1 ).

ADC could also be purified by a combination of ion exchange chromatography and affinity chromatography on organomercurial Sepharose (Prasad and Adiga, 1985b). The physicochemical properties and electrophoretic behaviour of both the preparations are the same.

\section{Enzyme assays}

Assays of ADC/ODC were carried out in Warburg flasks as detailed elsewhere (Ramakrishna and Adiga, 1975). Briefly, the reaction mixture for measurement of ADC 


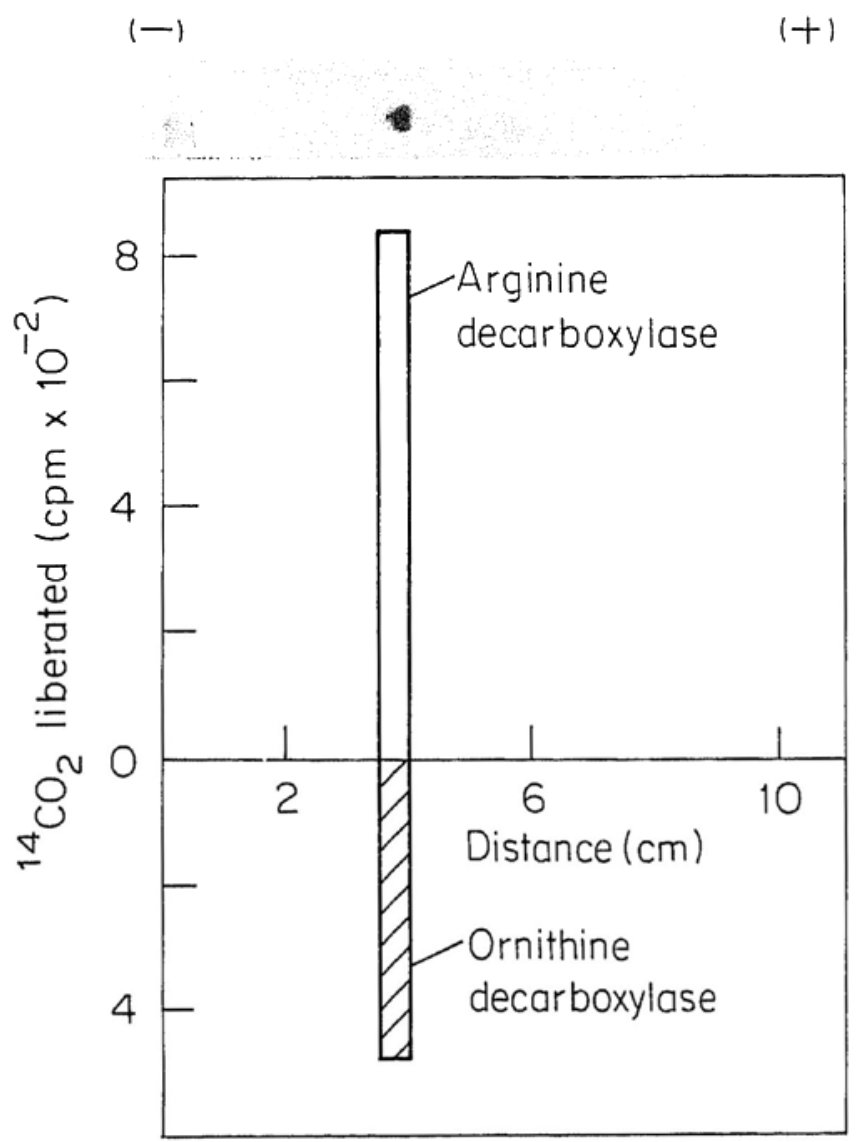

Figure 1. PAGE of ADC and ODC of C. sativus.

After electrophoresis (at $\mathrm{pH} 8 \cdot 3$ ) of the purified enzyme at $4^{\circ} \mathrm{C}$, the distribution of ADC and ODC activities was monitored by sectioning the gels and eluting at $4^{\circ} \mathrm{C}$ in $20 \mathrm{mM}$ Tris- $\mathrm{HCl}$ pH 7.6 containing $2 \mathrm{mM} 2$-mercaptoethanol and $10 \mu \mathrm{M}$ PLP. The enzyme activities were measured in the supernatant after removing the gel pieces by centrifugation.

activity consisted of $01 \mathrm{M}$ Tris- $\mathrm{HCl}, \mathrm{pH} 82,25 \mathrm{mM}$ dithiothreitol, $50 \mu \mathrm{M}$ pyridoxal phosphate (PLP) and $200,000 \mathrm{cpm}$ of $\mathrm{L}-\left[\mathrm{U}-{ }^{14} \mathrm{C}\right]$ arginine $(0 \cdot 36 \mu \mathrm{M})$. The reaction was initiated by the addition of substrate and incubated at $40^{\circ} \mathrm{C}$ for $2 \mathrm{~h}$. Quantification of ${ }^{14} \mathrm{CO}_{2}$ liberated during the post incubation period was done as described earlier (Ramakrishna and Adiga, 1975).

Assay of ODC was also conducted as described above using same reaction components but the labelled arginine was replaced by $\left[1-{ }^{14} \mathrm{C}\right]$-ornithine $(200,000 \mathrm{cpm}$, $15 \mu \mathrm{M}$ ). Ommission of unlabelled amino acid in the assay mixture did not alter our enzyme assay values. Similar observations have been made earlier by Goren et al. (1982). Blank values (without the addition of the enzyme) were routinely subtracted from the enzyme assay values.

\section{Unit activity}

One unit of enzyme activity is defined as that which liberates 1 pmol of ${ }^{14} \mathrm{CO}_{2} / 2 \mathrm{~h}$ at $40^{\circ} \mathrm{C}$. Specific activity is expressed in units $/ \mathrm{mg}$ of protein. 


\section{Other methods}

Polyacrylamide gel electrophoresis (PAGE) at $\mathrm{pH} 8 \cdot 3$ was carried out according to Davis (1964). PAGE at pH $4 \cdot 3$ on $5 \%$ gels was carried out as described by Reisfield et al. (1962). Sodium dodecyl sulphate (SDS) PAGE was performed according to Laemmli (1970). Antibodies were raised aginst the purified protein and double immunodiffusion on agar was performed as described by Ouchterlony (1967). Protein estimation was carried out according to Lowry et al. (1951) using crystalline bovine serum albumin as the standard.

\section{Results}

\section{Criteria of purity of $A D C$}

PAGE: The Sephadex G-150 eluate moved as a single stainable band during electrophoresis under non-denaturing conditions at $\mathrm{pH} 83$ (figure 1) and $4 \cdot 3$ (data not given). When subjected to SDS-PAGE, under non-reducing conditions, the protein again moved as a single band (data not given).

Immunological criterion: When the antibodies raised against the Sephadex G-150 eluate of the protein were allowed to interact with the purified protein, a single precipitin line was observed (data not shown).

Co-elution of $A D C$ and $O D C$ acitivities during gel filtration: When the Sephadex G-150 eluate (containing ADC activity) was tested for its substrate specificity, it was intriguing to find that ornithine also could be decarboxylated enzymatically by the same preparation efficiently. Since these two decarboxylating activities associated with the purified protein were excluded from Sephadex G-150, the possibility was considered that the dual enzyme activities might be due to a minor contaminant in the enzyme protein preparation. Therefore an attempt was made to separate them by further gel filtration on Sephacryl S-300. Under this condition also, both the activities were found to elute in the exclusion volume and the protein thus obtained could decarboxylate either arginine or ornithine in proportion to protein concentrations (table 1). The product of ornithine decarboxylase, putrescine could be identified on chromatograms (data not given).

Table 1. Decarboxylation of arginine and ornithine in Sephacryl S-300 eluted protein (purified ADC from cucumber seedlings).

\begin{tabular}{lcr}
\hline & \multicolumn{2}{c}{ Activity units } \\
Enzyme source & ADC & ODC \\
\hline Sephadex G-150 eluate & & \\
$\quad 65 \mu$ g protein & $4 \cdot 2$ & $7 \cdot 8$ \\
Sephacryl S-300 eluate & & \\
$55 \mu$ g protein & 3.6 & $7 \cdot 7$ \\
$110 \mu$ g protein & $7 \cdot 7$ & 15.8 \\
\hline
\end{tabular}


The purified enzyme upon electrophoresis at $\mathrm{pH} 8.3$ resolved into a single stainable protein band. When a duplicate gel was sliced ( $5 \mathrm{~mm}$ pieces) and individual slices were assayed for both the enzyme activities, both ADC and ODC activities banded at a region coincident with protein stain (figure 1). Both $\mathrm{ADC}$ and $\mathrm{ODC}$ assays were linear upto $200 \mu \mathrm{g}$ protein included in the assay mixture and $2 \mathrm{~h}$ of incubation time. ADC activity followed Michaelis-Menten kinetics with a $K_{m \text { ARG }} 0.5 \mathrm{mM}$ with $V_{\max }$ of $5.5 \mathrm{n} \mathrm{mol} / \mathrm{mg}$ protein $/ \mathrm{h}$. ODC also followed a similar pattern with $K_{m}$ for ornithine being $0.028 \mathrm{mM}$ and $V_{\max }$ of $277 \mathrm{p} \mathrm{mol} / \mathrm{mg}$ protein/h. Both the decarboxylating activities had a $\mathrm{pH}$ optima of 82 (data not shown).

\section{Modulation of $A D C$ and $O D C$ activities by phosphate and agmatine}

When agmatine, the immediate product of ARG-decarboxylation was included in the assay mixture, ADC activity was inhibited by $41 \%$ (table 2 ) whereas ODC activity was significantly stimulated ( 2.5 fold) under this condition. Addition of inorganic phosphate stimulated ADC activity by 2 -fold, while ODC activity was only marginally affected. When the effect of agmatine on ODC activity was tested at various concentrations, a linear dose-response could not be obtained (figure 2). Agmatine at lower concentrations i.e., upto $2.5 \mathrm{mM}$ had no discernible effect while at $5 \mathrm{mM}$ concentration was stimulatory to ODC activity. It is noteworthy that the selective stimulatory influence of agmatine on ODC and a similar effect of $P_{i}$ on ADC could be observed only if the freshly purified enzyme protein was used; aged enzyme preparations, while retaining significantly both the activities, were unaffected by these modulators for reasons not easily understood at present.

Table 2. Modulation of arginine and ornithine decarboxylation by $P_{i}$ and agmatine in Sephadex G-150 eluate (pure ADC preparation from cucumber seedlings).

\begin{tabular}{lcc}
\hline & \multicolumn{2}{c}{ Activity of control (\%) } \\
Additions (mM) & ADC & ODC \\
\hline Nil (control) & $100^{a}$ & $100^{a}$ \\
Agmatine (10) & 59 & 241 \\
$P_{i}(5 \cdot 0)$ & 182 & 116 \\
\hline${ }^{a}$ Control values for ADC and ODC are 82 and 170 \\
activity units/mg protein respectively. \\
$P_{i}$ and agmatine were included in the assay mixture \\
at indicated concentrations.
\end{tabular}

\section{Effect of putrescine}

Putrescine inhibited both ODC and ADC activities but to different extents (figure 2). The diamine at lower concentrations $(1 \mathrm{mM})$ did not influence ADC activity; even at 10 or $15 \mathrm{mM}$ concentrations, a maximum of about $53 \%$ of enzyme activity was obtained. Further inhibition was not observed on increasing putrescine concentration (figure 2). 


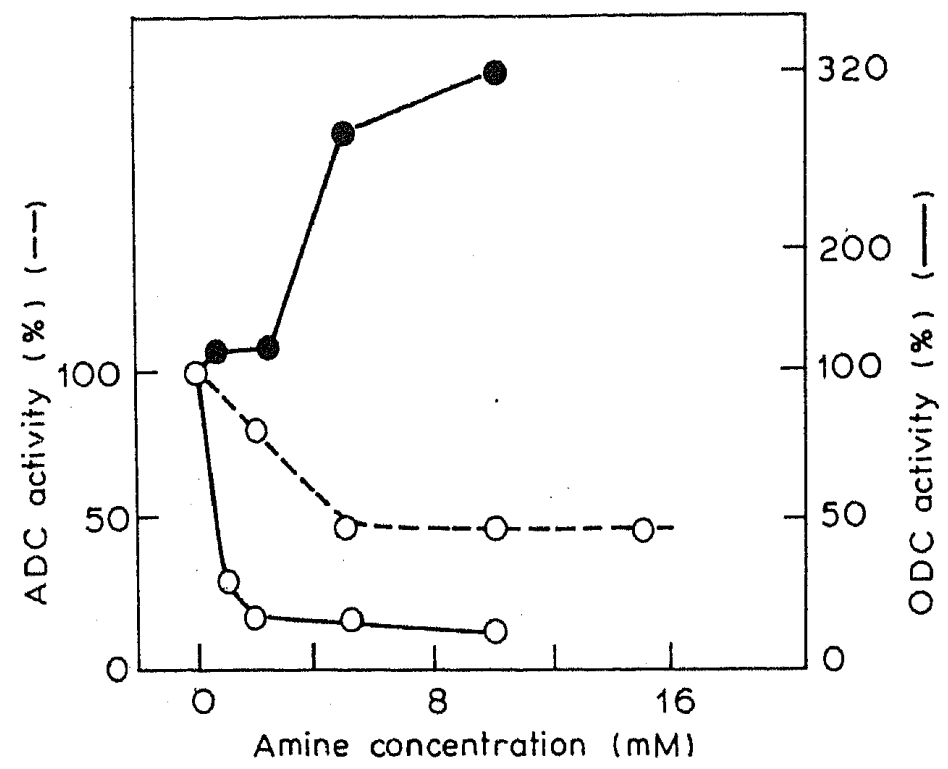

Figure 2. Effect of agmatine and putrescine on $\mathrm{ADC}$ and $\mathrm{ODC}$ activities of C. sativus. Agmatine ( $\bullet$ ) and putrescine ( o) were included to the ADC (---) or ODC (-) assay mixture at concentrations indicated and the enzyme activities are estimated as described in 'materials and methods.'

In marked contrast, OD C activity was clearly more susceptible to putrescine inhibition, since as low as $1 \mathrm{mM}$ of the diamine caused $70 \%$ inhibition and almost complete inhibition was achieved with $10 \mathrm{mM}$ of putrescine.

\section{Effect of DFMO}

This enzyme-activated irreversible inhibitor of mammalian ODC (Metcalf et al., 1978) exerted differential influence on ADC and ODC activities associated with the purified protein. When preincubated, the enzyme with DFMO at as low as $1 \mathrm{mM}$ markedly enhanced ADC activity (data not given). Thus, preincubation for 5 min resulted in 3 -fold increase in ADC activity which was further enhanced to 4-fold when this period was extended to $10 \mathrm{~min}$. Its concurrent effect on ODC activity was however clearly marginal (data not shown). Thus preincubation for $5 \mathrm{~min}$ at $1 \mathrm{mM}$ DFMO was ineffective in inhibiting ODC activity to any discernible extent, whereas at $2 \mathrm{mM}$ and on preincubation for $20 \mathrm{~min}$ about $50 \%$ inhibition of ODC activity could be elicited. Moreover, it could be clearly shown that this type of influence of DFMO on both ADC and ODC activities persisted even after dialysis. When the enzyme was preincubated with DFMO and assayed for ADC in the presence of $10 \mathrm{mM}$ unlabelled ornithine, ADC activity was still elevated. When ODC activity was assayed in the presence of $10 \mathrm{mM}$ arginine, after preincubation with DFMO, enzyme was inhibited to greater extent (table 3).

\section{Effect of citrulline and homoarginine}

ADC activity was inhibited approximately to $60 \%$ by $10 \mathrm{mM}$ citrulline, while ornithine decarboxylation was almost completely suppressed under these conditions. 
Table 3. Effect of DFMO on ADC/ODC activity from cucumber seedlings.

\begin{tabular}{|c|c|c|}
\hline \multirow[b]{2}{*}{ Assay conditions } & \multicolumn{2}{|c|}{ Activity units/mg protein } \\
\hline & $\mathrm{ADC}$ & ODC \\
\hline Control & 28 & 79 \\
\hline $\mathrm{DFMO}^{a}$ & $78(278)$ & $34(43)$ \\
\hline $\mathrm{DFMO}^{a}+$ dialyzed $^{b}$ & $78(278)$ & $33.5(42)$ \\
\hline DFMO $^{a}+$ ornithine $10 \mathrm{mM}$ & $82(292)$ & N.D. $e^{c}$ \\
\hline $\mathrm{DFMO}^{a}+$ arginine $10 \mathrm{mM}$ & N.D. ${ }^{c}$ & $11.5(14)$ \\
\hline Control + arginine $10 \mathrm{mM}$ & N.D. ${ }^{c}$ & $0^{d}$ \\
\hline Control + ornithine $10 \mathrm{mM}$ & $0^{d}$ & N.D. \\
\hline
\end{tabular}

values in parentheses are per cent activity of control.

${ }^{a}$ Enzyme was preincubated with $2 \mathrm{mM}$ DFMO for $20 \mathrm{~min}$ in a buffer containing $10 \mathrm{mM}$ Tris- $\mathrm{HCl}, \mathrm{pH} 7.6,2 \mathrm{mM}$ mercaptoethanol and $10 \mu \mathrm{M}$ PLP. The final concentration of the inhibitors in the assay was $0.1 \mathrm{mM}$. ${ }^{b}$ Preincubated ezyme was dialyzed (against 500 volumes for $3 \mathrm{~h}$ at $4^{\circ} \mathrm{C}$ ) and assayed for activity.

$c$ Not detectable due to dilution.

d Enzyme activity inhibited.

Homoarginine was also effective in curtailing both the ODC and ADC activities (table 4). Lysine when tested at $5 \mathrm{mM}$ concentration did not serve as a substrate for the enzyme under the assay conditions employed (data not shown).

Table 4. Effect of homoarginine and citrulline on ADC and ODC activities from cucumber seedlings.

\begin{tabular}{|c|c|c|}
\hline \multirow[b]{2}{*}{ Additions (mM) } & \multicolumn{2}{|c|}{ Activity units/mg protein } \\
\hline & $\mathrm{ADC}$ & ODC \\
\hline Nil (control) & 100 & 100 \\
\hline Citrulline (10) & $41(59)^{a}$ & $0(100)^{a}$ \\
\hline Homoarginine (10) & $4(96)^{n}$ & $0(100)^{a}$ \\
\hline
\end{tabular}

${ }^{a}$ Values represent per cent inhibition.

Citrulline and homoarginine were added to ADC/ODC standard assay mixture. Assay was started by adding Sephadex G-150 eluate (pure ADC preparation).

\section{Effect of pyridoxamine, $\mathrm{NaBH}_{4}$, semicarbazide, $\mathrm{NEM}$ and $\mathrm{KCl}$}

Addition of either $\mathrm{NaBH}_{4}(50 \mathrm{mM})$ or NEM $(10 \mathrm{mM})$ completely inhibited both ADC and ODC activities, indicating essential requirements for carbonyl function and sulphydryl groups for catalysis. Pyridoxamine $(20 \mathrm{mM})$ inhibited ADC activity to $64 \%$ and that of ODC to $43 \%$ while as low as $20 \mathrm{mM} \mathrm{KCl}$ was effective in inhibiting both the activities to comparable extents (table 5). 
Table 5. Effect of $\mathrm{KCl}$, pyridoxamine, sodium borohydride and NEM on ADC and ODC activities from cucumber seedlings.

\begin{tabular}{lcc}
\hline & \multicolumn{2}{c}{ Activity units/mg protein } \\
Additions (mM) & ADC & ODC \\
\hline $\mathrm{Nil}$ (control) & 72 & 171 \\
$\mathrm{KCl}(20)$ & $59(19 \cdot 9)^{a}$ & $120(30)^{a}$ \\
Pyridoxamine (20) & $26(64)^{a}$ & $98(43)^{a}$ \\
$\mathrm{NaBH}_{4}(50)$ & $0(100)^{a}$ & $10(94 \cdot 2)^{a}$ \\
$\mathrm{NEM}(10)$ & $0(100)^{a}$ & $15(92)^{a}$ \\
${ }^{a}$ Values represent per cent inhibition. \\
The additions were included in the standard assay mixture for \\
measuring ADC/ODC activity.
\end{tabular}

Effect of arginine and ornithine on the decarboxylation of labelled ornithine and arginine respectively

When both labelled arginine $(0.36 \mathrm{n} \mathrm{mol})$ and ornithine $(1.54 \mathrm{nmol})$ were included simultaneously in the assay mixture, it was found that both of them were efficiently utilized as substrates, since the amount of ${ }^{14} \mathrm{CO}_{2}$ liberated was more or less comparable to that arising out of individual enzyme activities (data not given). In other words, the presence of one of the unlabelled amino acid at the concentrations indicated did not seem to greatly affect the utilization of the other radioactive amino acid as the substrate.

\section{Cryptic nature of $O D C$ in crude extracts}

Data of table 6 clearly show that the O D C activity in crude extracts or during early purification steps was undetectable. The enzyme could be assayed only in the purified preparations. Upon mixing the crude extracts with the purified enzyme, ODC activity was found to be significantly inhibited.

Table 6. ODC activity of cucumber seedlings during various stages of purification.

\begin{tabular}{|c|c|}
\hline $\begin{array}{l}\text { Enzyme source } \\
\text { ( } \mu_{\mathrm{g}} \text { of protein) }\end{array}$ & $\begin{array}{c}\text { ODC activity units/mg } \\
\text { of protein }\end{array}$ \\
\hline Crude extracts (460) & Not detectable \\
\hline $\mathrm{MnCl}_{2}$ supernatant (200) & Not detectable \\
\hline DEAE-Cellulose eluate (200) & Not detectable \\
\hline Sephadex G-150 eluate (120) & 136 \\
\hline Sephadex G-150 eluate (120) & \\
\hline + crude extract (230) & 17 \\
\hline Sephadex G.150 eluate (120) & \\
\hline + crude extract $(460)$ & 60 \\
\hline
\end{tabular}




\section{Discussion}

The most significant observation in the present study, is the clearcut demonstration for the first time that the purified ADC from the cucumber seedlings has intrinsic ODC activity associated with it. It may be recalled that in prokaryotes where ADC and ODC activities co-exist and function in putrescine production under appropriate physiologyical conditions, their activities are not only associated with entirely different proteins, but are modulated differentially under various conditions (Morris and Fillingame, 1974; Pegg and Williams-Ashman, 1981). In the past, there have been a few reports describing specific amino acid decarboxylases which utilize other related amino acids as substrates. For example, in Lathyrus sativus seedlings, an enzyme catalyzes the decarboxylation of both homoarginine and lysine, though with different efficiencies (Ramakrishna and Adiga, 1976). In rat tissues, Pegg and McGill (1979) have shown that ODC could decarboxylate lysine when ODC activity was induced to a high level and lysine concentrations exceeded substantially those of ornithine. Similar results were obtained by Persson (1981) using testosterone-treated mouse kidney as the enzyme source. Furthermore, it was demonstrated that the two decarboxylating activities copurified with a constant ratio of specific activities and responded to different inhibitors in an analogous fashion in the mouse kidney extracts. Repeated attempts during the present study to quantify ODC activity either in crude extracts or during the earlier stages of purification were unsuccessful and the mechanisms underlying this cryptic nature of the ODC activity are currently ill-understood. Since, in mammalian and microbial systems, ODC activity can be masked by macromolecular inhibitors (Canellakis et al., 1979), it is conceivable that similar inhibitory factors (which are apparently lost upon purification) may contribute to our inability to assay ODC activity in cucumber crude extracts. The fact that ODC activity was not discernible in DEAE-cellulose eluate but became assayble in the final preparations favours such a view. Mixing experiments also lend credence to the above premise (table 6). The low specific activity of ADC preparation is due to the instability of the enzyme preparations, proteolytic degradation and tendency of the enzyme to get inactivated as the purification progressed (Prasad and Adiga, 1985 b). Since ODC activity is not detectable until the final stage of purification no further information can be given; moreover, it was not possible to determine the specific activity ratios of $\mathrm{ADC}$ and ODC.

That the dual activities associated with the purified enzyme may not be mediated through involvement of a single active site, is suggested by differential modulatory influence exerted by the various effectors of the two enzyme activities tested. Interestingly, the extent of inhibition $(50 \%)$ of purified ADC by agmatine under the assay conditions employed in this compares favourably with that encountered in vivo in agmatine treated cucumber cotyledons maintained in organ culture (Prasad and Adiga, 1985a). Phosphate-activation of ADC with no concurrent comparable influence on ODC as well as agmatine-stimulation of ODC activity attended by simultaneous profound inhibition of ADC are in line with the above premise. However, it may be pointed out that these regulatory characteristics are apparently labile since they were lost on aging of the enzyme. This is in accordance with the observation that regulatory/allosteric properties of several enzymes are rendered labile to such processes as proteolytic modification, dilution etc. (Reddy et al., 1980). It is also conceivable that 
significant activation of ODC achieved with agmatine, above a threshold value $(5 \mathrm{mM})$ could be a physiologically relevant control mechanism, in the sense that when agmatine accumulates beyond a certain critical intracellular level, ODC pathway of putrescine production may be favoured with concomitant inhibition of ADC, thereby sparing arginine for other competing vital cellular processes such as protein synthesis. This hypothesis implicates agmatine as a 'check post' for arginine flow into polyamine production in the plants.

Another line of evidence which is suggestive of involvement of different active site conformations for the catalytic efficiency of ADC and ODC activities associated with the same protein, stems from the differential extents of inhibition of activities by putrescine (figure 2). Near complete inhibition of ODC activity by the diamine in this plant system contrasts with the situation encountered with the mammalian enzyme where the diamine is only a weak competitive inhibitor (McCann et al., 1977). On the other hand, less efficient curtailing effect of putrescine on ADC activity compares favourably with the result obtained with ADC purified from L. sativus (Ramakrishna and Adiga, 1975).

Another rather intriguing aspect of this bifunctional enzyme is related to modulation of the two constituent activities by their respective irreversible inhibitor viz., DFMO. The observation that the maximum inhibition of this plant ODC activity by DFMO was confined to around $50 \%$ contrasts with the situation encountered with the mammalian enzyme (Mamont et al., 1980) but has a qualitative parallelism in some microbial systems. It may be recalled that ODC from both Escherichia coli and Klebsiella pneumoniae (Kallio and McCann, 1981) are refractory to this suicide enzyme inhibitor. That the latter aspect of similarity between the microbial and the cucumber enzyme extends to concurrent profound activation of ADC activity is clearly evident from the data of table 3 . It is significant that DFMO-facilitated argininedecarboxylation is sustained even in the presence of excess ornithine which is otherwise highly inhibitory to ADC activity (table 3). Intriguingly, in the presence of excess arginine, otherwise limited (50\%) inhibition of ODC activity by DFMO is significantly enhanced (90\%).

Despite these subtle differences in the modulatory aspects of the two decarboxylase activities associated with the protein, other results clearly support the notion that both the activities belong to the general category of amino acid decarboxylases. Thus, both the activities are sensitive to inhibition by $\mathrm{NEM}$ and $\mathrm{NaBH}_{4}$ and to a large extent by pyridoxamine indicating thereby an obligatory requirement for sulphydryl function and carbonyl groups. Results obtained with EDTA and $\mathrm{Mn}^{2+}$ clearly eliminate the possibility of the arginase + urease type (Lignowski and Splittstoesser, 1971) of reactivity contaminating the purified enzyme.

It appears that both ADC and ODC activities localized on the same protein have their individual domains that are interdependent in certain respects. The advantages that could possibly accrue to the plant in such an organization of dual activities on the protein molecule are several, among which concentration-dependent regulation of the individual enzyme activities by the respective substrates and common modulators may be the most crucial in the selection of the suitable enzymic pathway of putrescine synthesis under appropriate conditions. 


\section{Acknowledgements}

Financial assistance from the University Grants Commission, New Delhi and the generous gifts of DFMO and DFMA by Merrell-Dow Chemical Company, Cincinnatti, Ohio, USA are gratefully acknowledged.

\section{References}

Altman, A., Friedman, R. and Levin, N. (1982) Plant Physiol., 69, 876.

Bagni, N. and Speranza, A. (1977) in Plant Growth Regulators (eds T. Kudrev, I. Ivanova and E. Karano), (Sofia: Publishing House of the Bulgarian Academy of Sciences) p. 21.

Canellakis, E. S., Viceps-Madore, D., Kariakidis, D. A. and Heller, J. S. (1979) Curr. Top. Cell. Regul., $15,155$.

Cohen, E., Arad, S., Heimer, Y. M. and Mizrahi, Y. (1982) Plant Physiol., 70, 504.

Dai, Y. R., Kaur-Sawhney, R. and Galston, A. W. (1982) Plant Physiol., 69, 411.

Davis, B. J. (1964) Ann. N.Y. Acad. Sci., 121, 404.

Flores, H. E. and Galston, A. W. (1982) Science, 217, 1259.

Goren, R., Palavan, N. and Galston, A. W. (1982) J. Plant Growth Regul., 1, 61.

Heimer, Y. M., Mizrahi, Y. and Bachrach, U. (1979) FEBS Lett., 104, 146.

Kallio, A. and McCann, P. P. (1981) Biochem. J., 200, 69.

Kaur-Sawhney, R., Flores, H. and Galston, A. W. (1982) Plant Physiol., 69, 103.

Kyariakidis, E. A. (1983) Physiol. Plant, 57, 499.

Kyriakidis, D. A., Panagiotidis, C. A. and Georgatsos, J. G. (1983) Methods Enzymol., 94, 162.

Laemmli, U. K. (1970) Nature (London), 227, 680.

Lignowski, E. M. and Splittstoesser, W. E. (1971) Physiol. Plant, 25, 225.

Lowry, O. H., Rosebrough, N. J., Farr, A. L. and Randall, R. J. (1951) J. Biol. Chem., 193, 265.

Mamont, P. S., Bey, P. and Koch-Waser, J. (1980) in Polyamines in Biomedical Research (ed. J. M. Gaugas) (Chichester: John Wiley and Sons, A Wiley-Interscience Publication) p. 147.

McCann, P. P., Tardif, C. and Mamont, P. S. (1977) Biochem. Biophys. Res. Commun., 75, 948.

Metcalf, D. W., Cey, P., Danzin, C, Jung, M. J., Casara, P. I. and Vevert, J. P. (1978) J. Am. Chem, Soc., 100, 2551.

Morris, D. R. and Fillingame, R. H. (1974) Ann. Rev. Biochem., 43, 303.

Ouchterlony, O. (1967) in Handbook of Experimental Immunology (ed. D. M. Weir) (Oxford, Edinburgh: Blackwell Scientific Publications) p. 655

Palavan, N. and Galston, A. W. (1982) Physiol. Plant, 55, 438.

Pegg, A. E. and McGill, S. (1979) Biochim. Biophys. Acta, 568, 416.

Pegg, A. E. and Williams-Ashman, H. G. (1981) in Polyamines in Biology and Medicine (eds D. R. Morris and L. J. Morton), (New York: Marcel Dekker Inc.) p. 3.

Persson, L. (1981) Acta. Chem. Scand., 35, 451.

Prasad, G. L. and Adiga, P. R. (1985a) J. Plant Growth Regul., 4, 49.

Prasad, G. L. and Adiga, P. R. (1985b) J. Biosci., 7, 331.

Ramakrishna, S. and Adiga, P. R. (1975) Eur. J. Biochem., 59, 377.

Ramakrishna, S. and Adiga, P. R. (1976) Phytochemistry, 15, 83.

Reddy, A. R. V., Sobhanaditya, J. and Appaji Rao, N. (1980) J. Indian Inst. Sci., 62, 537.

Reisfeld, R. A., Lewis, U. J. and Williams, D. E. (1962) Nature (London), 195, 281.

Speranza, A. and Bagni, N. (1977) Z. Pflanzenphysiol., 81, 226. 